\title{
Influence of nanoparticles in polanga (calophyllum inophyllum) biodiesel operated in an unmodified diesel engine
}

Harish Venu

Vel Tech Rangarajan Dr.Sagunthala R\&D Institute of Science and Technology

Prabhu Appavu ( $\square$ prabhuappavu@gmail.com)

Anna University Chennai https://orcid.org/0000-0002-9765-4144

\section{Original Article}

Keywords: Nano additives, Polanga biodiesel, Surface area, Performance, Emission, Diesel engine

Posted Date: April 28th, 2020

DOI: https://doi.org/10.21203/rs.3.rs-24145/v1

License: (c) (1) This work is licensed under a Creative Commons Attribution 4.0 International License.

Read Full License 


\title{
Influence of nanoparticles in polanga (calophyllum inophyllum) biodiesel operated in an unmodified diesel engine
}

\author{
Harish Venu ${ }^{1}$, Prabhu Appavu ${ }^{2 *}$ \\ ${ }^{1}$ Department of Automobile Engineering, Vel Tech Rangarajan Dr.Sagunthala R\&D Institute \\ of Science and Technology, Chennai-600062 \\ ${ }^{2}$ Department of Mechanical engineering, College of Engineering, Guindy, Anna University, \\ Chennai-600025
}

*Corresponding Author: prabhuappavu@gmail.com

\begin{abstract}
The current research work emphases on analysing the characteristics of combustion, performance, and emissions of Polanga Biodiesel (PBD) fuelled single cylinder diesel engine with $\mathrm{Al} 2 \mathrm{O} 3$ nano-additives added at concentration of 25ppm and 50ppm. The results were compared with the baseline diesel fuel at varying engine loads $(25 \%, 50 \%, 75 \%$ and $100 \%)$ in a agriculture based single cylinder diesel engine of 17.5 Compression ratio at constant engine speed of 1500rpm. Al2O3 nano-additives were blended with PBD using magnetic stirrer and ultrasonicator. Experimentation results revealed that, the nanoparticles addition in PBD improved the combustion and emission characteristics of base fuel due to higher surface area to volume ratio of nano-additives. Moreover, Al2O3 nanoparticles addition enhanced the brake thermal efficiency (BTE) and lowered the brake specific fuel consumption (BSFC) by $6.58 \%$ and $7.38 \%$ respectively. Subsequently, the emissions of HC, CO, NOx and smoke opacity were improved with the addition of fuel borne additives in PBD owing to improved combustion efficiency.
\end{abstract}

Keywords: Nano additives; Polanga biodiesel; Surface area; Performance; Emission; Diesel engine

\section{Introduction}

Increasing dependency on diesel fuel over transportation sector and surge in air pollution levels, has thrived search for a potential alternative feedstock which is environmentally benign as well as bio-based for existing unmodified DI diesel engine. The 
rapid increase in automobiles has resulted in higher dependency on fossil fuels and also higher fuel exhaust from internal combustion engines. Compression ignition (CI) engines emit higher oxides of nitrogen (NOx) and carbon dioxide $\left(\mathrm{CO}_{2}\right)$ emissions which are the major greenhouse gases responsible for global warming. Other gases include regulated emissions such as hydrocarbon (HC), Carbon monoxide (CO), smoke opacity and unregulated emissions like acetaldehyde, formaldehyde, acetone and toluene. From the 1970s till 2010, the rate of increase in Green House Gases (GHGs) is estimated at $1.8 \%$ every year, which is subsequently responsible for increasing earth temperature by $2^{\circ} \mathrm{C}$. Another usage of fossil fuels includes agricultural sector, power/transportation and mining sectors. Hence, Many researchers were performed on diesel engines for its capability with alternative fuels in the mere future as there is random fossil fuel depletion. Reduction of harmful gases in any of the above sector, even on a minimal scale can add to environmental sustainability and can replace tonnes of harmful gases plunged into the atmosphere.

Usage of alternative fuels paves the way for sustainable development, the dependency of renewable resources and environmental energy and conservation process. Among various alternative energy sources, biodiesel plays a vital role in reducing the high flash point range and improved lubricity. Added with, biodiesel is of non-toxic in nature and is of renewable and biodegradable in nature. However, certain drawbacks associated with biodiesel utilization are poorer fuel atomization and higher viscous nature which eventually results in improved NOx emissions and lowered BTE. Several research articles with biodiesel application have shown substantial lowering in $\mathrm{HC}, \mathrm{CO}$ and unregulated emissions with higher NOx spectrum. Several research investigations have proved that appending metal oxide based additives in base fuel facilitates the oxidation process and increases the combustion efficiency of diesel engine along with minimized emissions.

Nanoparticles $\left(10^{-9} \mathrm{~m}\right.$ scale) addition in base fuel is found to exhibit improved engine combustion and performance characteristics. Venu Harish and Venkataramanan Madhavan [1] examined the influence of $\mathrm{Al}_{2} \mathrm{O}_{3}$ nanoparticles in ternary fuels (biodiesel/diesel/ethanol) blends with various injection timings. They perceived that the nanoparticle combustion was better in retarded injection timing in lowering the harmful tailpipe emissions such as $\mathrm{CO}, \mathrm{HC}$, NOx and smoke emissions. Venu Harish and Venkataramanan Madhavan [2] also established that the metal oxide nanoparticles inclusion in ternary fuel component is better to that of appending oxygenated additives such as DEE (diethyl ether) in the consent of developed combustion and performance phenomenon. Several investigations were done using Polanga 
biodiesel as a probable alternative fuel replacing the mineral diesel fuel. Bari and Hossain [3] investigated in a diesel engine with biodiesel comparing the performance with the baseline diesel fuel. They found that the specific fuel consumption of biodiesel is higher by $10 \%$ than the mineral diesel owing to the lowered calorific value of biodiesel even though the thermal efficiency is slightly closer to diesel. Moreover, $\mathrm{CO}$ and $\mathrm{HC}$ emissions of biodiesel run engine were approximately 50\% lesser than that of conventional diesel fuel though $\mathrm{NOx}$ emissions were higher by 33\%, respectively. Yuvarajan et al. [4] experimented in a single cylinder diesel engine and found, plain biodiesel of $100 \% \mathrm{v} / \mathrm{v}$ could be a potential alternate fuel in an unmodified diesel engine.

Even though various literature were done on Polanga biodiesel and alumina nano additives at individual capacities, there were no reported literatures on analyzing the effect of $\mathrm{Al}_{2} \mathrm{O}_{3}$ nano-additives at various concentrations (25ppm and 50ppm) in Polanga biodiesel (PBD) on the effect of characteristics of performance, combustion and emissions on an unmodified diesel engine. With this strategic conception, the following experimental work is performed with diesel, Polanga biodiesel and Polanga biodiesel appended with $\mathrm{Al}_{2} \mathrm{O}_{3}$ nanoadditives.

\section{Experimental Material \& Methods}

\subsection{Nanoparticle synthesis}

$\mathrm{Al}_{2} \mathrm{O}_{3}$ nano-sized particles were synthesized using sol-gel combustion method where the $0.5 \mathrm{M}$ aluminium nitrate solution is blended in $50 \mathrm{ml} \mathrm{H}_{2} \mathrm{O}$ at $22^{\circ} \mathrm{C}$ and stirred using magnetic stirrer. Then $0.05 \mathrm{M}$ urea is mixed with aluminium nitrate and treated for 30 minutes until $\mathrm{pH} 2$ solution is attained. Further titration with $25 \mathrm{ml}$ of $\mathrm{H}_{2} \mathrm{O}$ and $0.1 \mathrm{M}$ sodium hydroxide was done till $\mathrm{pH} 6$ solution is attained. After the formation of clady gel $(\mathrm{pH}=8)$ with sodium hydroxide addition, the sample is dried at $150^{\circ} \mathrm{C}$ for 12 hours and $\mathrm{Al}_{2} \mathrm{O}_{3}$ nanoparticles were procured in a container and were allowed to dry at $300^{\circ} \mathrm{C}$ and 2 hours in the furnace. The flowchart illustrating the synthesis procedure of alumina nanoparticles were shown in Figure 1. The physical properties of synthesized $\mathrm{Al}_{2} \mathrm{O}_{3}$ nanoparticles were detailed in Table 1. Figure 2 depicts the flowchart for the preparation of $\mathrm{Al}_{2} \mathrm{O}_{3}$ nanoparticles. Figure 3 shows the SEM and TEM spectroscopy of synthesized $\mathrm{Al}_{2} \mathrm{O}_{3}$ nanoparticles.

\subsection{Polanga Biodiesel preparation and test fuel preparation}

Polanga oil biodiesel is synthesized using conventional transesterification method of treating raw Polanga oil with methanol with a catalyst in a batch reactor. Initially, the 
Polanga oil is subjected to $80^{\circ} \mathrm{C}$ preheating for removing the available moisture in the blend. Since the FFA of raw Polanga oil is higher, the acid pretreatment process is done by reacting it with sulphuric acid $\left(\mathrm{H}_{2} \mathrm{SO}_{4}\right)$. Hence, 1.5 Molar ratio of raw oil to methanol and $0.6 \% \mathrm{v} / \mathrm{v}$ $\mathrm{H}_{2} \mathrm{SO}_{4}$ were heated in the batch reactor for $65^{\circ} \mathrm{C}$ for 2 hours at $450 \mathrm{rpm}$ speed. Blending the nanoparticle is done using ultrasonicator operated with $60 \mathrm{kHz}$ operating frequency and 440 $\mathrm{kW}$ power operated for $20 \mathrm{~min}$. It is found that the nanoparticles in PBD remained stable for about 96 hrs. PBD+25 ppm $\mathrm{Al}_{2} \mathrm{O}_{3}$ is prepared by blending 25ppm $\mathrm{Al}_{2} \mathrm{O}_{3}$ nanoparticles with $100 \%$ Polanga biodiesel while $\mathrm{PBD}+50 \mathrm{ppm} \mathrm{Al}_{2} \mathrm{O}_{3}$ is prepared by blending 50ppm $\mathrm{Al}_{2} \mathrm{O}_{3}$ nanoparticles with $100 \%$ Polanga biodiesel. The fuel properties were calculated as per American Society for Testing and Materials (ASTM) standards as shown in Table 2.

\subsection{Experimental setup}

For the current experimentation, Kirloskar-TAF1 diesel engine was used which is agriculturally based, single cylinder, naturally aspirated, four-stroke DI diesel engine with a rated power output of $4.2 \mathrm{~kW}$ at $1500 \mathrm{rpm}$. The specifications of used test engine were given in Table 3. The test engine unit comprises a fuel delivery unit, electrical dynamometer for load adjustment, Data Acquisition Systems (DAS), smoke opacimeter (AVL 437 C) and AVL five gas analyzer (measuring $\mathrm{CO}, \mathrm{O}, \mathrm{HC}, \mathrm{CO}_{2}$ and $\mathrm{NOx}$ ). Experimentations were done on 5 load intervals of $0 \%, 25 \%, 50 \%, 75 \%$ and $100 \%$ respectively and in between two test fuels, the engine is allowed to be run with neat diesel fuel for $20 \mathrm{~min}$ for attaining standard operating rhythm. Figure 4 shows a schematic of the test engine setup.

\subsection{Uncertainty analysis}

Miscalculations and uncertainties can appear from several influences alike choosing and calibration of devices, varying atmospheric circumstances, trials and interpretations, etc. Uncertainty can be classified into two factors such as fixed and random errors. Fixed error deals with repeatability while random error deals mainly with critical quantities. $\Delta \mathrm{X}$, which is defined as measured variable associated uncertainties is assessed by Gaussian distribution as shown in eqn. 1 with $\pm 2 \sigma$ limit of confidence. The mean value upon which the measured value depends were indicated by $2 \sigma$. Xi denotes the reading numbers, and $\sigma$ indicates standard deviation. Equation 2 indicates uncertainties in parameters calculated in which the functions such as $\mathrm{X}_{1}$ and $\mathrm{X}_{2}$ till $\mathrm{Xn}$ of the $\mathrm{R}$ range represents taken readings (in numbers). Equation 3 represents the uncertainties associated with measuring instruments in which $\Delta \mathrm{R}$ is the range of uncertainties and is calculated by RMS value of observed error values and is 
indicated in Table 4 while Table 5 shows the uncertainties associated with measured parameters.

$$
\begin{gathered}
\Delta X_{i}=\frac{2 \sigma_{i}}{\bar{X}_{i}} * 100 \\
\mathrm{R}=\mathrm{f}(\mathrm{X} 1, \mathrm{X} 2, \mathrm{X} 3, \ldots \ldots \ldots \ldots . . \mathrm{Xn}) \\
\Delta R=\sqrt{\left[\left(\frac{\partial R}{\partial X_{1}} \Delta X_{1}\right)^{2}+\left(\frac{\partial R}{\partial X_{2}} \Delta X_{2}\right)^{2}+\left(\frac{\partial R}{\partial X_{3}} \Delta X_{3}\right)^{2}+\ldots \ldots \ldots \ldots \ldots . . .\left(\frac{\partial R}{\partial X_{n}} \Delta X_{n}\right)^{2}\right]}
\end{gathered}
$$

Where, $\mathrm{R}$ in eqn.2 represents the function of $\mathrm{X} 1, \mathrm{X} 2, \ldots \ldots . \mathrm{Xn}$ and $\mathrm{X} 1, \mathrm{X} 2, \ldots \ldots \mathrm{Xn}$ represents number of readings taken. Hence $\Delta \mathrm{R}$ is computed by RMS (root mean square) of errors associated with measured parameters. The uncertainties of various measuring instruments were illustrated in Table 4. By using eqn.3, the uncertainties in various measured parameters were evaluated and tabulated in Table 5.

\section{Results and discussion}

\subsection{Combustion characteristics}

Figure 5 shows the variation of in-cylinder pressure for all the test fuels at $100 \%$ engine load condition. It is observed that at all the test fuel blends exhibits almost similar cylinder pressure style. PBD and DIESEL fuel exhibits in-cylinder pressure range of about 81.23bar and 79.56 bar respectively. The reason for lowered cylinder pressure for DIESEL is shortened delay period which results in combustion getting more uniform followed by lessened peak pressure [5, 6]. Moreover, from Table 2, we can observe that DIESEL fuel has improved calorific value which is responsible for consuming lowered fuel at combustion and high combustion efficiency of DIESEL is also a factor for shortened peak pressure $[7,8]$. Addition of $\mathrm{Al}_{2} \mathrm{O}_{3}$ nano-additives at 25ppm and 50ppm fraction to PBD resulted in improved peak pressure which could be perhaps attributed to the improved thermal conductivity of the resulting nano-fuel mixture $[9,4]$. The higher thermal conductivity of nano-fuel causes the fuel combustion to begin earlier thus resulting in higher in-cylinder peak pressure. From the figure, we can infer that with increasing concentration of $\mathrm{Al}_{2} \mathrm{O}_{3}$ nano $\mathrm{Al}_{2} \mathrm{O}_{3}$ nano-additive concentration in PBD to 50ppm, the combustion begins earlier, which may be attributed to increment in ignition quality and improved coefficient of thermal conductivity of $\mathrm{Al}_{2} \mathrm{O}_{3}$ nanoadditives. Similar results with observed pressure pattern were reported in several literatures with different nanoparticles in base fuel. 
The HRR at every crank angle on behalf of various fuel blends were calculated using the correlation derived from the 1 st law of thermodynamics by equation 4 :

$$
\frac{\mathrm{dQ}}{\mathrm{d} \theta}=\left(\frac{\gamma}{\gamma-1} \mathrm{P} \frac{\mathrm{dV}}{\mathrm{d} \theta}\right)+\left(\frac{1}{\gamma-1} \mathrm{~V} \frac{\mathrm{dP}}{\mathrm{d} \theta}\right)+\dot{\mathrm{Q}}_{\mathrm{lw}}
$$

Where, Qn represents the net heat release rate (HRR) (J/degCA), P represents instantaneous in-cylinder pressure $\left(\mathrm{N} / \mathrm{m}^{2}\right), \mathrm{V}$ showcases the instantaneous in-cylinder volume $\left(\mathrm{m}^{3}\right), \boldsymbol{\theta}$ is crank angle (degree) and $\gamma$ is defined as the ratio of specific heats $\mathrm{Cp} / \mathrm{Cv}(\mathrm{kJ} / \mathrm{kgK})$ depending mainly on the temperature factor and influences the intensity of $\frac{d Q_{n}}{d \theta}$ and $\dot{Q}_{\mathrm{lw}}$. $\dot{\mathrm{Q}_{\mathrm{Iw}}}$ is defined as the blow by losses which are defined by Rakopoulas [10]. The gross HRR can be calculated by equation 5 :

$$
\frac{d Q_{g}}{d \theta}=\frac{d Q_{n}}{d \theta}+\frac{d Q_{1 w}}{d \theta}
$$

Where $\frac{\mathrm{dQ}_{\mathrm{lw}}}{\mathrm{d} \theta}$ defines the gross HRR to the combustion chamber walls [10].

Figure 6 illustrates the variation of HRR for all the test fuels at 100\% engine load condition. It is observed that DIESEL and PBD exhibit maximum HRR of about 92.37J/degCA and 81.43 J/degCA. Higher HRR for DIESEL fuel can be attributed to a higher calorific value which results in higher heat generation during combustion. With the increase in the concentration of $\mathrm{Al}_{2} \mathrm{O}_{3}$ nano-additives, the HRR increases further owing to increase in ignition quality and coefficient of thermal conductivity of $\mathrm{Al}_{2} \mathrm{O}_{3}$ nano additives. This improved thermal conductivity of resulting fuel mixture accelerates the rate of combustion of fuel precursors and thereby liberating the maximum heat release rate. These research findings are in good accordance with the previous research findings, where the HRR is improved with appending of nano materials in the base fuel.

\subsection{Performance Characteristics}

Figure 7 represents the variation of BTE of DIESEL, PBD, PBD+25ppmAl $\mathrm{Al}_{2} \mathrm{O}_{3}$ and $\mathrm{PBD}+50 \mathrm{ppmAl}_{2} \mathrm{O}_{3}$ all over the engine load condition. At $100 \%$ engine load, DIESEL fuel exhibits highest $\mathrm{BTE}$ of $32.19 \%$, followed by $\mathrm{PBD}+50 \mathrm{ppmAl}{ }_{2} \mathrm{O}_{3} \quad$ (30.63\%), $\mathrm{PBD}+25 \mathrm{ppmAl}_{2} \mathrm{O}_{3}(29.94 \%)$ and $\mathrm{PBD}(28.74 \%)$ respectively. The higher BTE of mineral DIESEL in comparison with oxygenated blends were owing to lowered fuel viscosity and improved calorific value of the blend [11]. At $100 \%$ load, the BTE of PBD+25ppmAl $\mathrm{O}_{2} \mathrm{O}_{3}$ and $\mathrm{PBD}+50 \mathrm{ppmAl}_{2} \mathrm{O}_{3}$ were $4.21 \%$ and $6.58 \%$ higher than PBD blend. This is because, with 
$\mathrm{Al}_{2} \mathrm{O}_{3}$ nano additive, the atomization of fuel droplets were increased, thus promoting the combustion efficiency followed by higher BTE $[12,13,14]$. Moreover, it is interesting that $\mathrm{BTE}$ of $\mathrm{PBD}+50 \mathrm{ppmAl}_{2} \mathrm{O}_{3}$ blend exhibits higher $\mathrm{BTE}$ than $\mathrm{PBD}+25 \mathrm{ppmAl}_{2} \mathrm{O}_{3}$ blend throughout the engine load condition. The $\mathrm{Al}_{2} \mathrm{O}_{3}$ nano-additive acts as an oxygen buffer as well as a potential catalyst with increasing concentration (20 ppm to 50ppm). These results are in good accordance with previous research works with biodiesel and nano-additives [15, $16,17]$.

Figure 8 shows the variation of BSFC of all the test fuels at varying engine load condition. It is observed that, with an increase in engine load, the BSFC reduces which can be attributed to the engine utilizing higher fuel quantum for maintaining a constant speed (1500 rpm) at higher engine loads. At $100 \%$ load, the BSFC of PBD is highest $(12.72 \mathrm{~g} / \mathrm{kWh})$, followed by $\mathrm{PBD}+25 \mathrm{ppmAl} \mathrm{O}_{2}(11.82 \mathrm{~g} / \mathrm{kWh})$ and $\mathrm{PBD}+50 \mathrm{ppmAl} \mathrm{Ol}_{2} \mathrm{O}_{3}(11.783 \mathrm{~g} / \mathrm{kWh})$ and DIESEL (10.347 $\mathrm{g} / \mathrm{kWh}$ ) respectively. All the biodiesel blends resulted in higher BSFC than DIESEL fuel which is attributed to the lowered calorific value of blends. In comparison with DIESEL fuel, the viscosity of PBD, $\mathrm{PBD}+25 \mathrm{ppmAl}_{2} \mathrm{O}_{3}$ and $\mathrm{PBD}+50 \mathrm{ppmAl} \mathrm{A}_{2} \mathrm{O}_{3}$ is lower than PBD by about $7.08 \%$ and $7.38 \%$ respectively. The presence of $\mathrm{Al}_{2} \mathrm{O}_{3}$ nano-additive in PBD improves the oxidation process and subsequently lowers the fuel consumed [18]. BSFC of $\mathrm{PBD}+25 \mathrm{ppmAl}_{2} \mathrm{O}_{3}$ is lower than $\mathrm{PBD}+50 \mathrm{ppmAl}_{2} \mathrm{O}_{3}$ all over the engine load condition. The presence of in-built oxygen content in $\mathrm{Al}_{2} \mathrm{O}_{3}$ nano-additive accelerates the combustion process and improves the combustion efficiency and thus lowers the BSFC subsequently. Lowered BSFC with nanoparticle addition were also reported in several research articles [17, 19].

\subsection{Emission Characteristics}

Figure 9 illustrates the variation of NOx emissions for all the test fuels throughout the engine load condition. It can be observed that NOx emissions keep on increasing with the increase in engine load for all the test fuels owing to improve in-cylinder gas temperatures at higher load spectrums. Among the test fuels, DIESEL fuel exhibits lowered NOx emissions in comparison with $\mathrm{PBD}, \mathrm{PBD}+25 \mathrm{ppmAl} \mathrm{A}_{2} \mathrm{O}_{3}$ and $\mathrm{PBD}+50 \mathrm{ppmAl} \mathrm{Al}_{2} \mathrm{O}_{3}$ blends owing to the presence of oxygenates in the blend. At full engine load condition, the NOx emissions of $\mathrm{PBD}+25 \mathrm{ppmAl}_{2} \mathrm{O}_{3}$ and $\mathrm{PBD}+50 \mathrm{ppmAl} \mathrm{O}_{3}$ were lower than PBD by about $8.75 \%$ and $11.73 \%$ respectively. This could be attributed to the improvement in cetane number characteristics with increasing $\mathrm{Al}_{2} \mathrm{O}_{3}$ concentration [20, 21]. 
$\mathrm{Al}_{2} \mathrm{O}_{3}+\mathrm{NO} \rightarrow 2 \mathrm{AlO}+\frac{1}{2} \mathrm{~N}_{2}$

At improved in-cylinder temperatures, $\mathrm{Al}_{2} \mathrm{O}_{3}$ molecule reacts with $\mathrm{NO}$ to release the molecules, $2 \mathrm{AlO}$ and $1 / 2 \mathrm{~N} 2$, lessening the NOx formation tendency as represented in equ.5. These results are in coherence with several research studies $[15,16,17]$ which also reported lowered NOx with biodiesel and nanoparticle addition. At full load condition (100\% load), the NOx emissions of DIESEL, $\mathrm{PBD}, \mathrm{PBD}+25 \mathrm{ppmAl}_{2} \mathrm{O}_{3}$ and $\mathrm{PBD}+50 \mathrm{ppmAl} \mathrm{O}_{3}$ were about $13.06 \mathrm{~g} / \mathrm{kWh}, 16.17 \mathrm{~g} / \mathrm{kWh}, 14.75 \mathrm{~g} / \mathrm{kWh}$ and $14.27 \mathrm{~g} / \mathrm{kWh}$ respectively.

Figure 10 displays the distinction of $\mathrm{HC}$ emissions for all the test fuels throughout the engine load condition. It can be seen that $\mathrm{HC}$ emissions improves with increasing loads owing to more fuel entering into the combustion chamber thus resulting in several rich mixture zones, poor combustion, thus emitting higher unburnt fuel fractions, i.e. higher $\mathrm{HC}$ emissions. The presence of inbuilt $\mathrm{O}_{2}$ in biodiesel blend helps in sustaining the combustion thus resulting in lowered $\mathrm{HC}$ emissions for $\mathrm{PBD}, \mathrm{PBD}+25 \mathrm{ppmAl}_{2} \mathrm{O}_{3}$ and $\mathrm{PBD}+50 \mathrm{ppmAl} \mathrm{O}_{2}$ respectively. This is because; the presence of $\mathrm{Al}_{2} \mathrm{O}_{3}$ nano-additive with higher thermal conductivity improves the combustion process and lowers the possibility of rich mixture zone formation, thus lowering the $\mathrm{HC}$ emissions. $\mathrm{HC}$ emissions of $\mathrm{PBD}+50 \mathrm{ppmAl} \mathrm{O}_{3}$ are lower than $\mathrm{PBD}+25 \mathrm{ppmAl}_{2} \mathrm{O}_{3}$ throughout the engine load condition. This could be attributed to the presence of sufficient nanoparticles which enhances the rate of combustion thus generating $\mathrm{O}_{2}$ assisted combustion followed by lowered $\mathrm{HC}$ emissions. The obtained results were in good accordance with the previous research findings [22, 23, 24] that have reported lowered $\mathrm{HC}$ emissions with nanoparticle addition in base fuel. At $100 \%$ load, the $\mathrm{HC}$ emissions of DIESEL, PBD, PBD+25ppmAl ${ }_{2} \mathrm{O}_{3}$ and $\mathrm{PBD}+50 \mathrm{ppmAl}_{2} \mathrm{O}_{3}$ were about $0.533 \mathrm{~g} / \mathrm{kWh}, 0.468$ $\mathrm{g} / \mathrm{kWh}, 0.35 / \mathrm{kWh}$ and $0.32 \mathrm{~g} / \mathrm{kWh}$ respectively.

Figure 11 shows the variation of smoke emissions for all the test fuels throughout the engine load condition. It is observed that smoke emissions increases with increasing engine load condition for all the test fuels, owing to the presence of excess fuel quantity which subsequently causes rich mixture zone, incomplete/poor combustion followed by improved smoke spectrum. In contrast with DIESEL, the smoke emissions of PBD, PBD+25ppmAl $\mathrm{O}_{3}$ and $\mathrm{PBD}+50 \mathrm{ppmAl}_{2} \mathrm{O}_{3}$ were lower by about $7.39 \%, 30.62 \%$ and $41.97 \%$ respectively. This is due to the occurrence of in-built $\mathrm{O}_{2}$ content in biodiesel that promotes the rate of combustion 
followed by lowered smoke opacity. At $100 \%$ engine load, in comparison with PBD, the smoke emitted by $\mathrm{PBD}+25 \mathrm{ppmAl}_{2} \mathrm{O}_{3}$ and $\mathrm{PBD}+50 \mathrm{ppmAl}_{2} \mathrm{O}_{3}$ were lowered by about $25.09 \%$ and $37.34 \%$ respectively. This can be possible because of the presence of $\mathrm{Al}_{2} \mathrm{O}_{3}$ nanoadditive which improves the evaporation rate of the fuel. With increasing nanoparticle concentration to $50 \mathrm{ppm}$, the smoke is further reduced which can be attributed to the presence of sufficient quantum of nanoparticles providing $\mathrm{O}_{2}$ assisted combustion thus lowering the formation of soot precursors and suppressing the NOx formation. These observations are in good agreement with findings of several researchers $[14,15,16]$ where nanoparticle addition lowered the smoke emission formation. At $100 \%$ engine load condition, the smoke emitted by DIESEL, PBD, $\mathrm{PBD}+25 \mathrm{ppmAl}_{2} \mathrm{O}_{3}$ and $\mathrm{PBD}+50 \mathrm{ppmAl}{ }_{2} \mathrm{O}_{3}$ were about $1.67 \%, 1.54 \%$, $1.15 \%$ and $0.96 \%$ respectively.

Figure 12 displays the variation of $\mathrm{CO}$ emissions with respect to varying engine load condition. From the figure, it can be found that $\mathrm{CO}$ emissions increase with increase in engine load condition owing to the higher quantum of fuel taking part in combustion with the unchanged air quantity inside the cylinder which eventually causes a rich mixture thus liberating higher CO emissions. At 100\% engine load, in comparison with DIESEL, the CO emissions of PBD, $\mathrm{PBD}+25 \mathrm{ppmAl}{ }_{2} \mathrm{O}_{3}$ and $\mathrm{PBD}+50 \mathrm{ppmAl}{ }_{2} \mathrm{O}_{3}$ were lowered by about $7.24 \%$, $30.71 \%$ and $36.45 \%$ respectively. Perhaps, this can be attributed to lowered $\mathrm{O}_{2}$ availability in DIESEL which hinders the conversion of $\mathrm{CO}$ to $\mathrm{CO}_{2}$. Addition of nanoparticle in PBD at a concentration of $25 \mathrm{ppm}$ and 50ppm lowers the CO emission by about $25.3 \%$ and $31.49 \%$ respectively, which could be attributed to the presence of $\mathrm{Al}_{2} \mathrm{O}_{3}$ nano-additives providing excess $\mathrm{O}_{2}$ during combustion thereby facilitating the faster $\mathrm{CO}_{2}$ conversion followed by lessened CO emissions.

At higher in-cylinder temperatures, $\mathrm{Al}_{2} \mathrm{O}_{3}$ nanoparticle further breaks up to $\mathrm{Al}_{2} \mathrm{O}$ and $\mathrm{O}$. " $\mathrm{Al}_{2} \mathrm{O}$ " molecule is remarked as a highly unstable compound at higher in-cylinder temperatures within the combustion chamber which can further dissociate to $2 \mathrm{Al}$ and $\frac{1}{2} \mathrm{O}_{2}$. The available excess oxygen molecule further rejoins with $\mathrm{CO}$ to get transformed to a $\mathrm{CO}_{2}$ molecule as illustrated in the following Equation (6-8): 
$\mathrm{O}+\mathrm{CO} \rightarrow \mathrm{CO}_{2}$

With increasing nanoparticle concentration to 50ppm, $\mathrm{CO}$ emissions further reduce by $8.28 \%$ to $2.6 \mathrm{~g} / \mathrm{kWh}$ which could be attributed to improved fuel properties of $\mathrm{PBD}+50 \mathrm{ppmAl}_{2} \mathrm{O}_{3}$ as well as the presence of sufficient concentration of nano-additives boosting the rate of combustion efficiency. These experimental results were in good agreement with previous research findings $[15,21,25]$ where the nanoparticle assisted in lowering the $\mathrm{CO}$ emissions subsequently.

\section{Conclusion}

The current experimental study deals with analyzing the diesel engine's characteristics of performance, combustion and emissions in a single cylinder engine run with PBD blended with $\mathrm{Al}_{2} \mathrm{O}_{3}$ nano-additives at 25ppm and 50ppm concentration. Nano-additives were blended with PBD using magnetic stirrer and ultrasonication process. Tests were performed only after the dispersion of nanoparticles is checked for non-settling for about 96 hrs. Experimentation was done using DIESEL as a baseline, $\mathrm{PBD}, \mathrm{PBD}+25 \mathrm{ppmAl}_{2} \mathrm{O}_{3}$ and $\mathrm{PBD}+50 \mathrm{ppmAl} \mathrm{O}_{3}$. Based on experimentation, the following conclusions can subsequently be drawn:

- Addition of $\mathrm{Al}_{2} \mathrm{O}_{3}$ nano-additives at a concentration of $25 \mathrm{ppm}$ and 50ppm in $\mathrm{PBD}$ improves the combustion characteristics (HRR, Cylinder pressure) owing to the improved surface area to volume ratio of nanoparticles improving the thermal conductivity of fuel mixture which subsequently improves the combustion efficiency.

- The obtained BTE of PBD blend is lower than DIESEL fuel at all the engine load conditions. However, with $\mathrm{Al}_{2} \mathrm{O}_{3}$ nanoparticle addition, the $\mathrm{BTE}$ is increased by $4.21 \%$ and $6.58 \%$ with $25 \mathrm{ppm}$ and 50ppm concentration. Similarly, the BSFC is lowered by $7.38 \%$ with nanoparticle addition. These are attributed to the improved calorific value of the blends which increases the energy density of fuel mixture and thus utilizing lesser quantum of fuel to maintain the engine speed constant (1500 rpm)

- Emission wise, PBD blends emits higher NOx emissions with respect to DIESEL fuel owing to in-built $\mathrm{O}_{2}$ content in the blend which favours the NOx formation chemistry. However, the addition of $\mathrm{Al}_{2} \mathrm{O}_{3}$ nano-additive acts as a potential reduction catalyst and 
breaks the chain of nitrogen and oxygen molecules and thereby subduing the NOx formation process. With $\mathrm{Al}_{2} \mathrm{O}_{3}$ nanoparticle addition, other emissions such as hydrocarbon (HC), carbon monoxide (CO) and smoke opacity were reduced by $30.32 \%$, $31.49 \%$ and $37.34 \%$ respectively which could possibly be attributed to the presence of nano-additives acting as oxygen buffer and supplies $\mathrm{O}_{2}$ during combustion thus lowering the possibility of formation of fuel-rich zones and lowered exhaust emissions.

\section{Nomenclature}

$\begin{array}{ll}\mathrm{Al}_{2} \mathrm{O}_{3} & \text { Aluminium oxide nanoparticle } \\ \text { BSEC } & \text { Brake Specific Energy Consumption } \\ \text { BTE } & \text { Brake Thermal Efficiency } \\ \mathrm{CO} & \text { Carbon monoxide } \\ \mathrm{CO}_{2} & \text { Carbon dioxide } \\ \mathrm{CI} & \text { Compression Ignition } \\ \text { DI } & \text { Direct Injection } \\ \mathrm{HRR} & \text { Heat Release Rate } \\ \mathrm{HC} & \text { Hydrocarbon } \\ \text { NOx } & \text { Oxides of Nitrogen } \\ \text { TEM } & \text { Transmission Electron Microscope } \\ \text { SEM } & \text { Scanning Electron Microscope }\end{array}$

\section{Authors' contributions}

Both authors equally contributed to this work

\section{Acknowledgements}

Not applicable

\section{Funding:}

The authors acknowledge that there are no external funding/grants received for this research work. 


\section{Competing interests:}

The authors declare no competing financial interest.

\section{Disclosure statement:}

No potential conflict of interest was reported by the authors.

\section{Availability of data and material:}

Not applicable

\section{Authors' information:}

Harish Venu, completed his Ph.D from Anna University in 2017. Presently he is working as an Assistant Professor in the Department of Automobile Engineering in Vel Tech Rangarajan Dr.Sagunthala R\&D Institute of Science \&Technology, Chennai. He has published several research papers in Elsevier and Springer international journals. His areas of interests include bio-fuels, alternate fuels, nano additives, sustainable energy sources and internal combustion engines.

Prabhu Appavu received his Bachelor degree (B.Tech) from Pondicherry University in 2005, and Master degree (M.E) from Anna University, Chennai in 2009. In January 2015, he started his Ph.D. program in Mechanical Engineering at Anna University, Chennai, India. His research interest includes biofuels, alternative fuels, nano additives, IC engines.

\section{References:}

[1] Venu Harish and Venkataramanan Madhavan. Effect of Al2O3 nanoparticles in biodiesel-diesel-ethanol blends at various injection strategies: Performance, combustion and emission characteristics, Fuel. 2016a;186:176-189.

[2] Venu Harish and Venkataramanan Madhavan. Effect of diethyl ether and Al2O3 nano additives in diesel-biodiesel-ethanol blends: Performance, combustion and emission characteristics. J. Mech. Sci. Tech. 2017a;31:409. Bari S and Hossain SN. Performance and emission analysis of a diesel engine running on palm oil diesel (POD). Energy Procedia. 2019;160:92-99.

[3] Bari S and Hossain SN. Performance and emission analysis of a diesel engine running on palm oil diesel (POD). Energy Procedia. 2019;160:92-99. 
[4] Yuvarajan D, Surendran R, Vinoth Kumar V and Devanathan R. Role of Additives on Emission Characteristics of Methyl Ester in Constant Speed Diesel Engine. Appl. Mech. Mater. 2016;852:729-733.

[5] Devarajan Y, Munuswamy DB, Mahalingam A, Nagappan B. Performance, Combustion, and Emission Analysis of Neat Palm Oil Biodiesel and Higher Alcohol Blends in a Diesel Engine. Energy Fuels. 2017a;31(12):13796-13801.

[6] Venu H, Subramani L, Raju VD. Emission reduction in a DI diesel engine using exhaust gas recirculation (EGR) of palm biodiesel blended with $\mathrm{TiO} 2$ nano additives, Renew. Energy. 2019a. doi: 10.1016/j.renene.2019.03.078.

[7] Devarajan Y, Munuswamy DB, Mahalingam A. Performance, combustion and emission analysis on the effect of ferrofluid on neat biodiesel. Proc. Saf. Environ. Protec. $2017 b ; 111: 283-291$.

[8] Vallapudi DR, Makineni HK, Pisipaty SK and Venu H. Combined impact of EGR and injection pressure in performance improvement and NOx control of a DI diesel engine powered with tamarind seed biodiesel blend. Environ. Sci. Pollut. Res. 2018;25(36):36381-36393.

[9] Venu H, Raju VD and Subramani L. Combined effect of influence of nano additives, combustion chamber geometry and injection timing in a DI diesel engine fuelled with ternary (diesel-biodiesel-ethanol) blends. Energy 2019b;174:386-406.

[10] Rakopoulos DC. Heat release analysis of combustion in heavy-duty turbocharged diesel engine operating on blends of diesel fuel with cottonseed or sunflower oils and their bio-diesel. Fuel. 2012;96:524-534.

[11] Venu Harish and Venkataramanan Madhavan. Influence of diethyl ether (DEE) addition in Ethanol-Biodiesel-Diesel (EBD) and Methanol-Biodiesel-Diesel (MBD) blends in a diesel engine. Fuel. 2017b;189:377-390.

[12] Yetter RA, Risha GA and Son SF. Metal particle combustion and nanotechnology. Proc. Combus. Inst. 2009;32(2):1819-1838.

[13] De Luca LT, Galfetti L, Severini F, Meda L, Marra G, Vorozhtsov AB. Sedoi VS and Babu VA. Burning of nano-aluminized composite rocket propellants, Combust. Explo. Shock Waves. 2005;41(6):680-692.

[14] Tyagi H, Phelan PE, Prasher R, Peck R, Lee T, Pacheco JR and Arentzen P. Increased hot-plate ignition probability for nanoparticle-laden diesel fuel, Nano letters. 2008;8(5):1410-1416. 
[15] Hosseini SH, Taghizadeh-Alisaraei A, Ghobadian B, and Abbaszadeh-Mayvan A. Effect of added alumina as nano-catalyst to diesel-biodiesel blends on performance and emission characteristics of CI engine, Energy. 2017;124:543-552.

[16] Patel HK and Kumar S. Experimental analysis on performance of diesel engine using mixture of diesel and bio-diesel as a working fuel with aluminum oxide nanoparticle additive, Therm. Sci. Eng. Prog. 2017;4:252-258.

[17] Prabu A and Anand RB. Emission control strategy by adding alumina and cerium oxide nano particle in biodiesel, J. Energy Inst. 2016;89(3):366-372.

[18] Aalam CS and Saravanan CG. Effects of nano metal oxide blended Mahua biodiesel on CRDI diesel engine. Ain Shams Eng. J. 2017;8(4):689-696.

[19] Shaafi T and Velraj R. Influence of alumina nanoparticles, ethanol and isopropanol blend as additive with diesel-soybean biodiesel blend fuel: combustion, engine performance and emissions, Renew. Energy. 2015;80:655-663.

[20] Kao MJ, Ting CC, Lin BF and Tsung TT. Aqueous aluminum nanofluid combustion in diesel fuel, J. Test. Evaluation. 2007;36(2):186-190.

[21] Sadhik Basha J and Anand RB. Role of nanoadditive blended biodiesel emulsion fuel on the working characteristics of a diesel engine, J. Renew. Sustain. Energy. 2011;3(2):023106.

[22] Basha JS and Anand RB. An experimental study in a CI engine using nanoadditive blended water-diesel emulsion fuel, Int. J. Green Energy. 2011;8(3):332-348.

[23] Basha JS and Anand RB. The influence of nano additive blended biodiesel fuels on the working characteristics of a diesel engine, J. Braz. Soc. Mech. Sci. Eng. 2013;35(3):257-264.

[24] Rao MS and Anand RB. Performance and emission characteristics improvement studies on a biodiesel fuelled DICI engine using water and $\mathrm{AlO}(\mathrm{OH})$ nanoparticles, Appl. Therm. Eng. 2016;98:636-645.

[25] Sivakumar M, Sundaram NS and Thasthagir MHS. Effect of aluminium oxide nanoparticles blended pongamia methyl ester on performance, combustion and emission characteristics of diesel engine, Renew. Energy. 2018;116:518-526. 
Figures

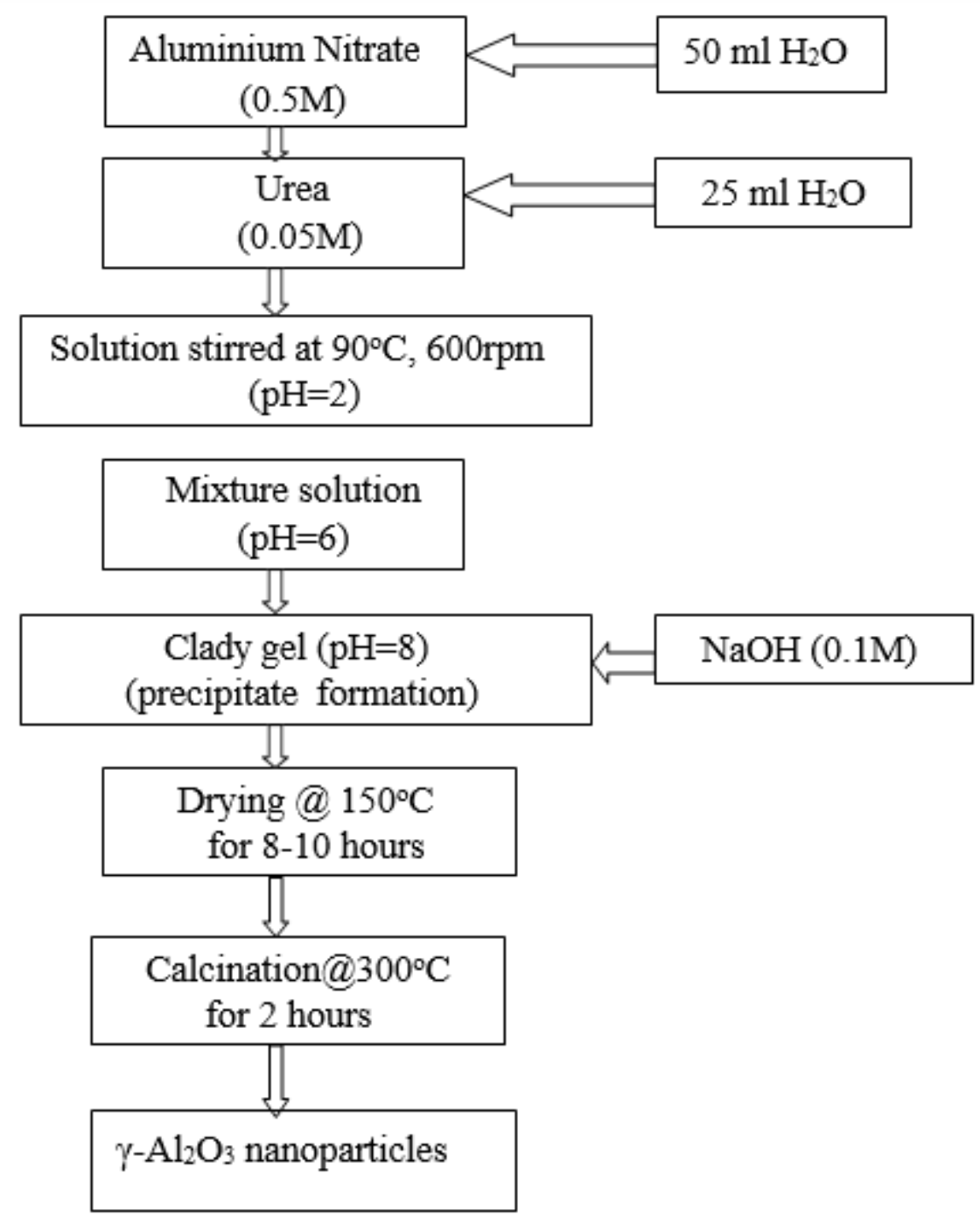

Figure 1

Flowchart illustrating synthesis of alumina nanoparticles 


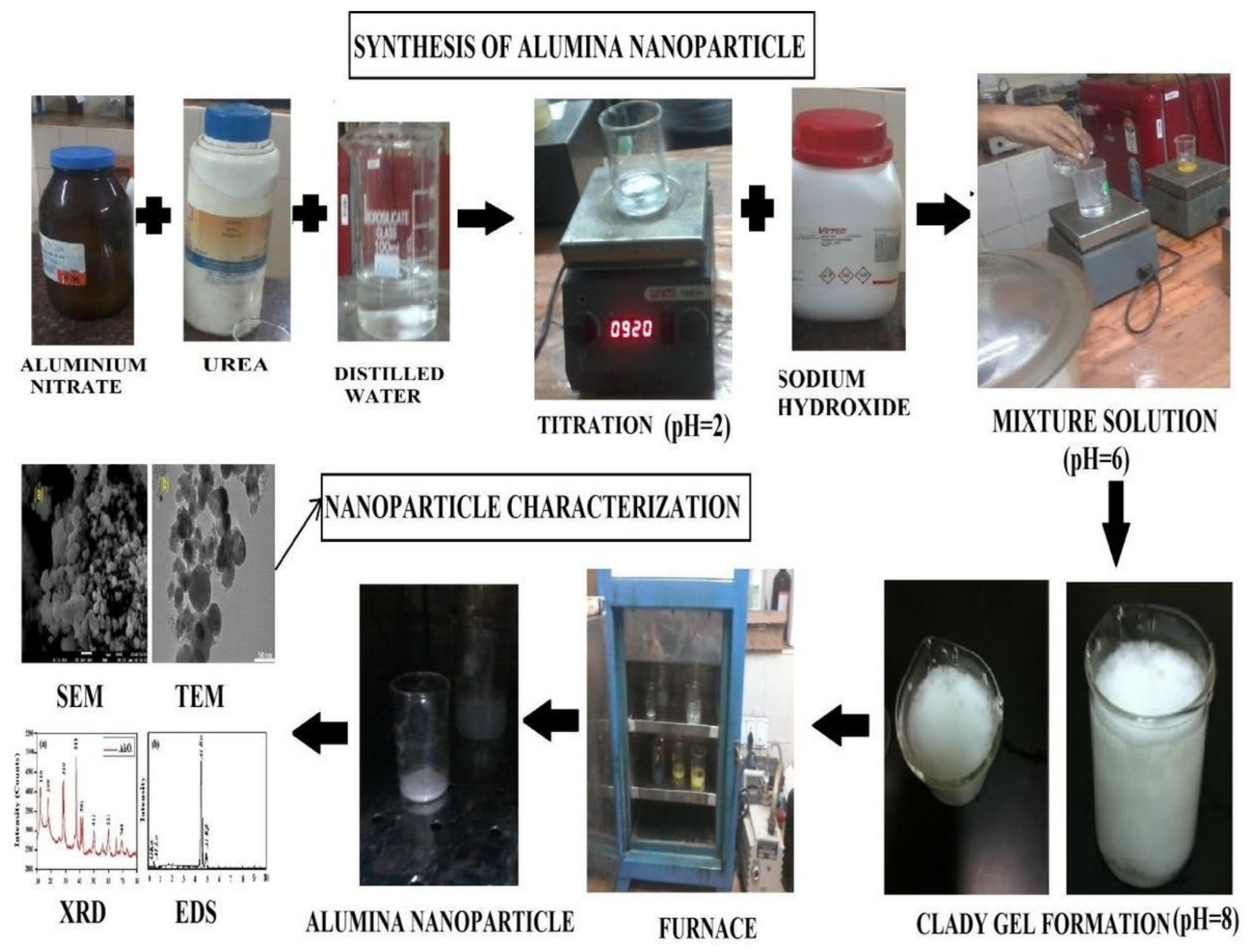

Figure 2

Flowchart indicating the nanoparticle preparation
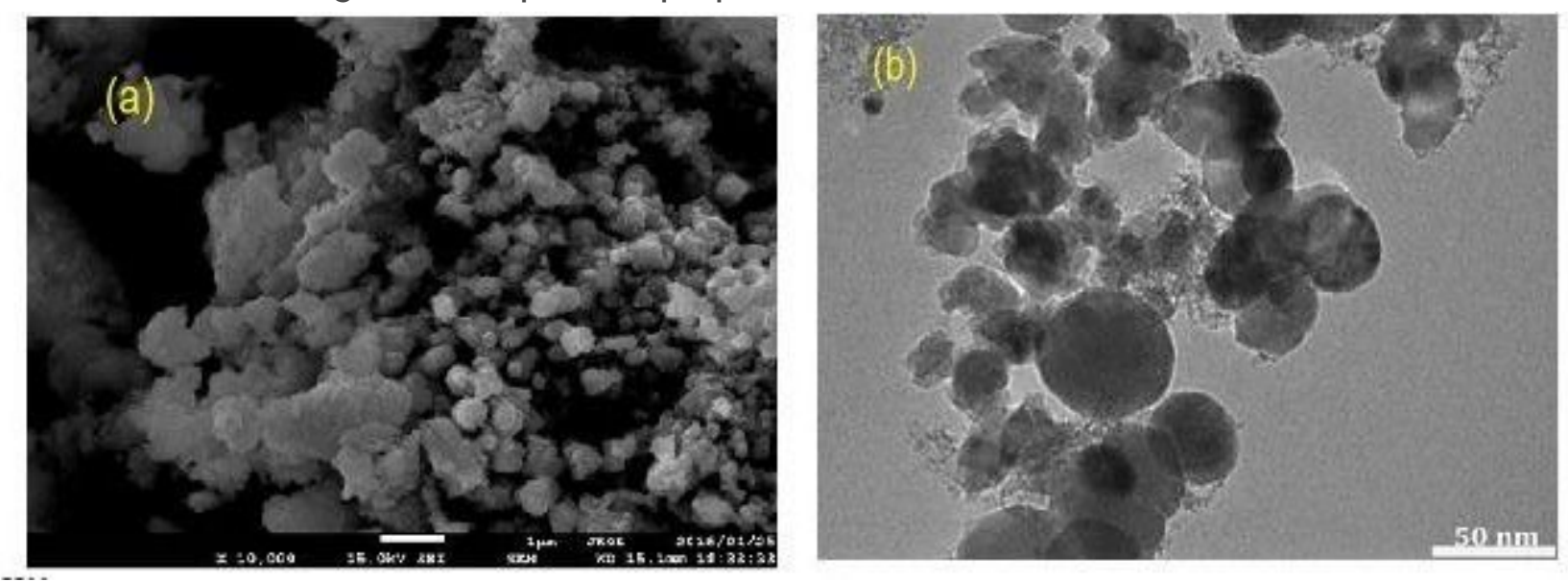

Figure 3

Characterization of Al2O3 nanoparticles a) SEM b) TEM 


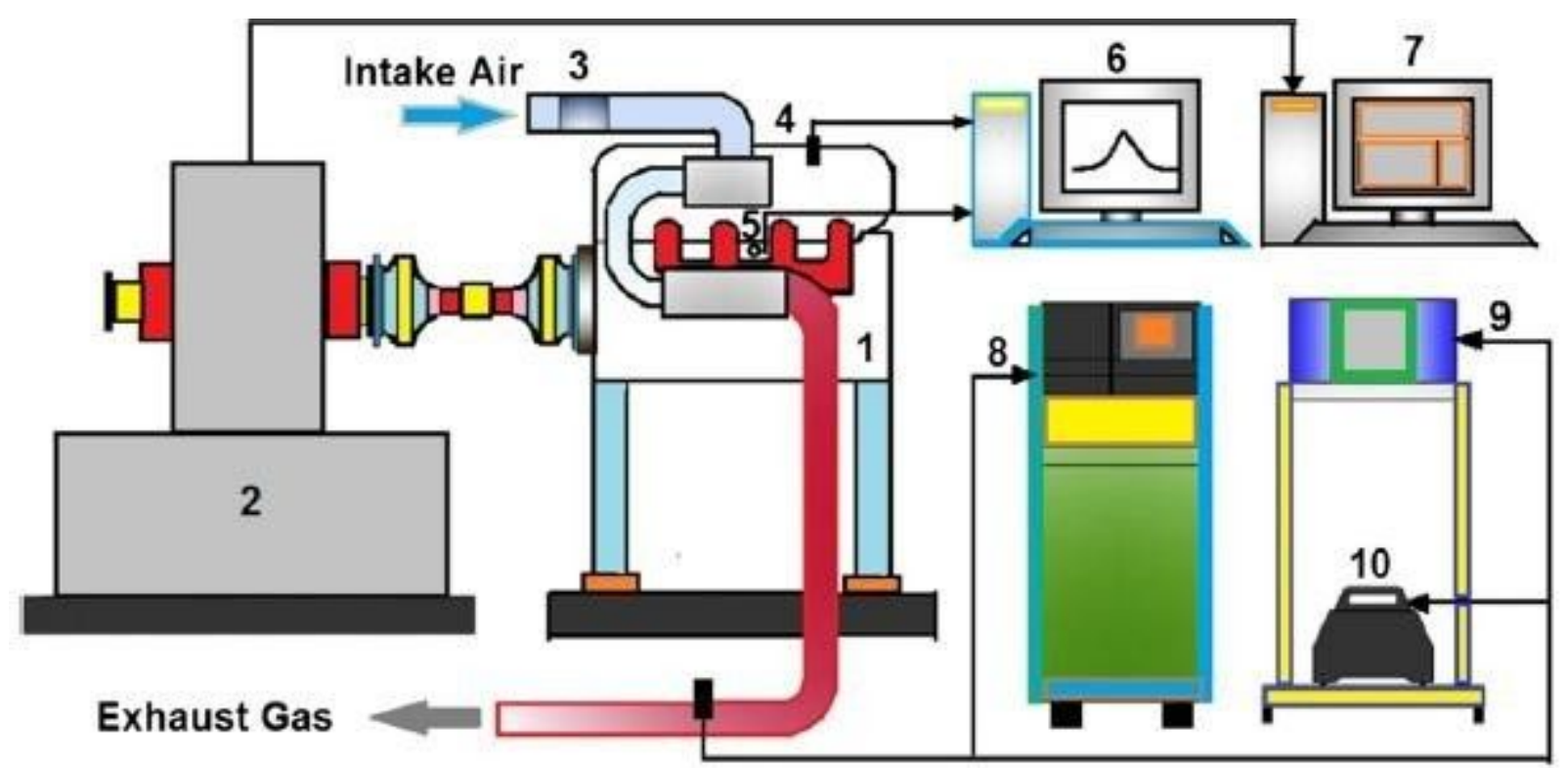

1. Test engine

2. Eddy current dynamometer

3. Air mass sensor

4. Pressure sensor

5. Accelerometer
6. Data aquisition system (DAS)

7. Dynamometer controller

8. Bosch gas analyser

9. AVL digas analyser

10. Smoke opacity meter

Figure 4

Layout of experimental setup 


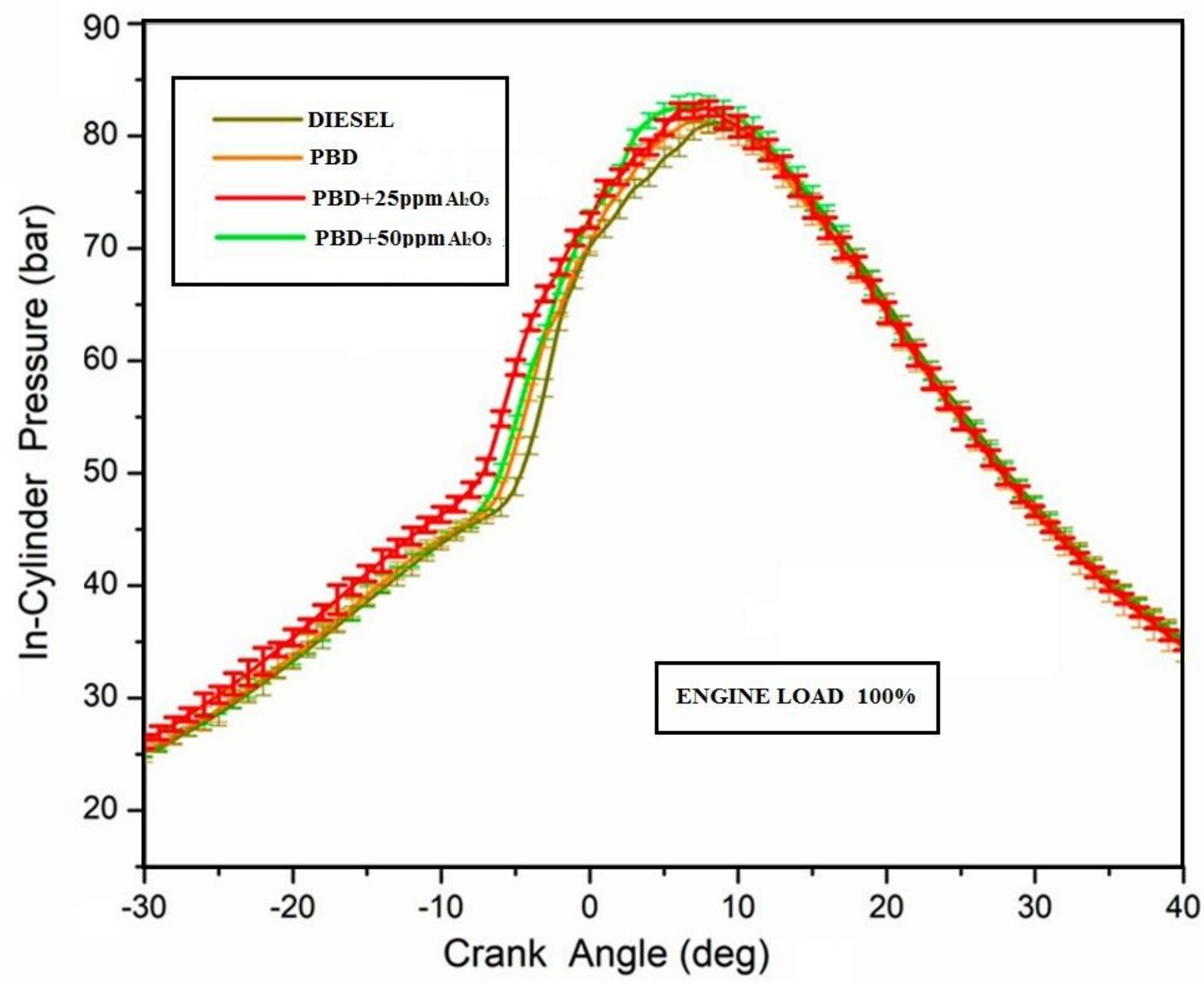

Figure 5

Variation of in-cylinder pressure with crank angle at $100 \%$ engine load 


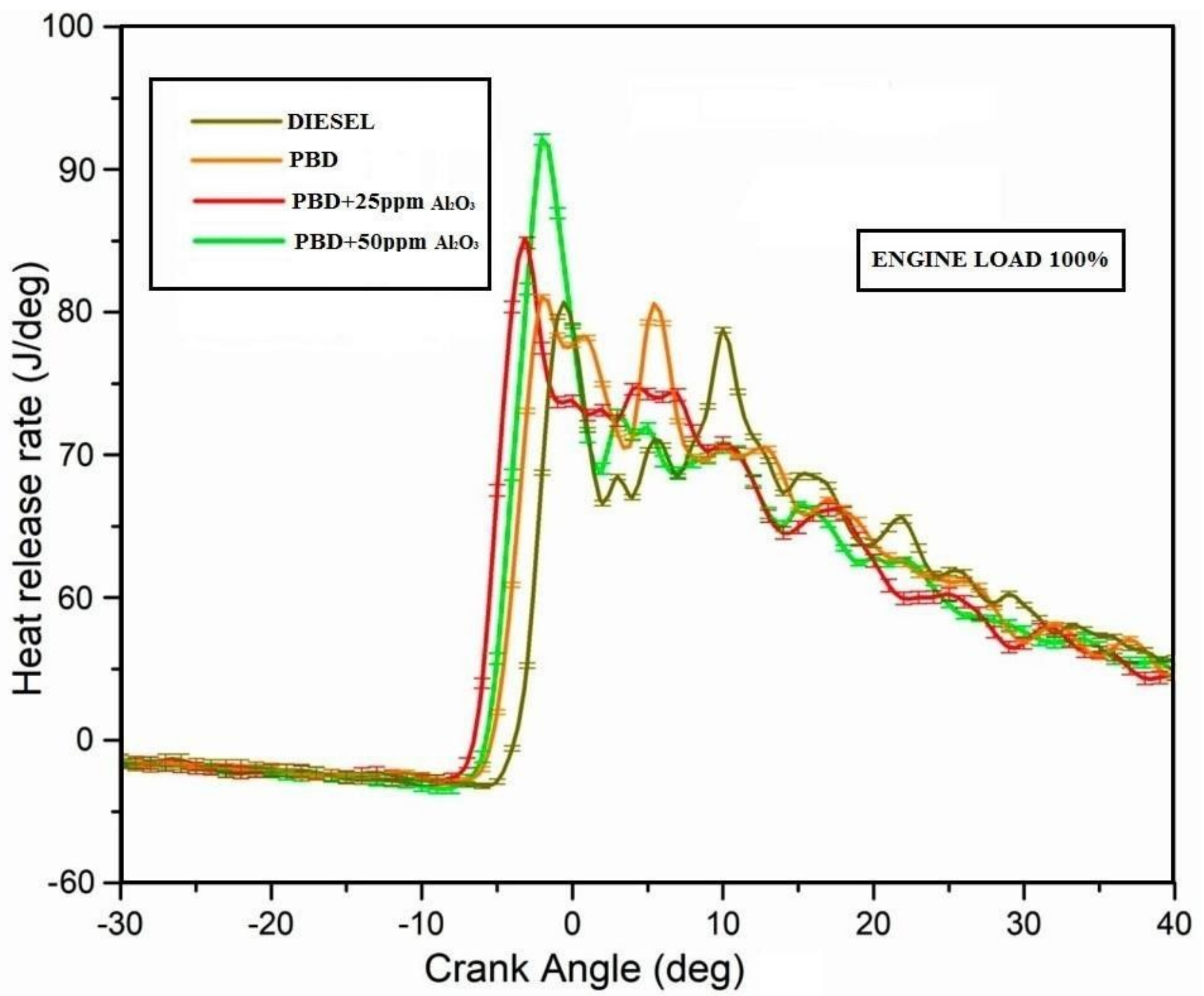

Figure 6

Variation of heat release rate with crank angle at $100 \%$ engine load 


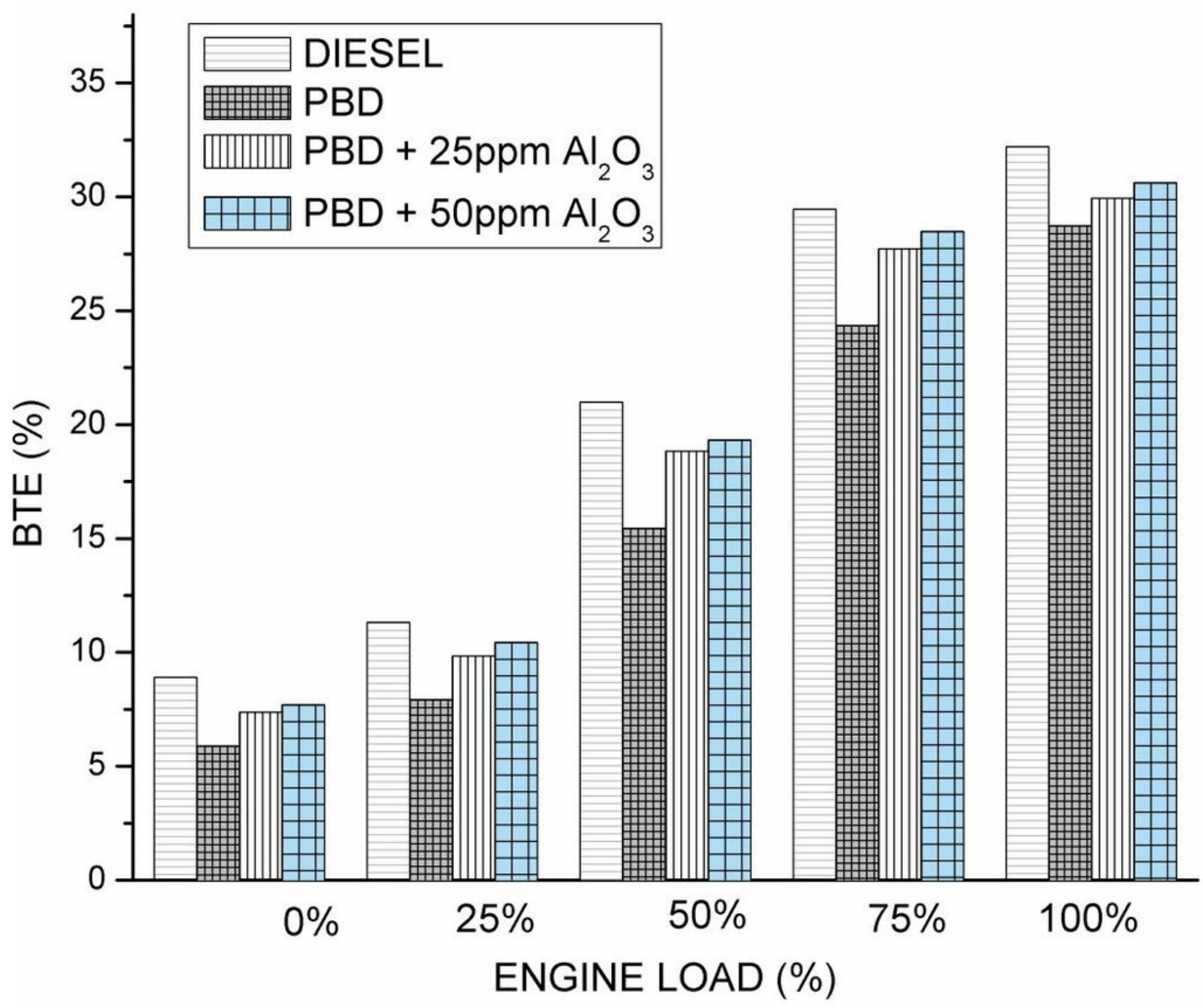

Figure 7

Variation of brake thermal efficiency (BTE) with respect to engine load 


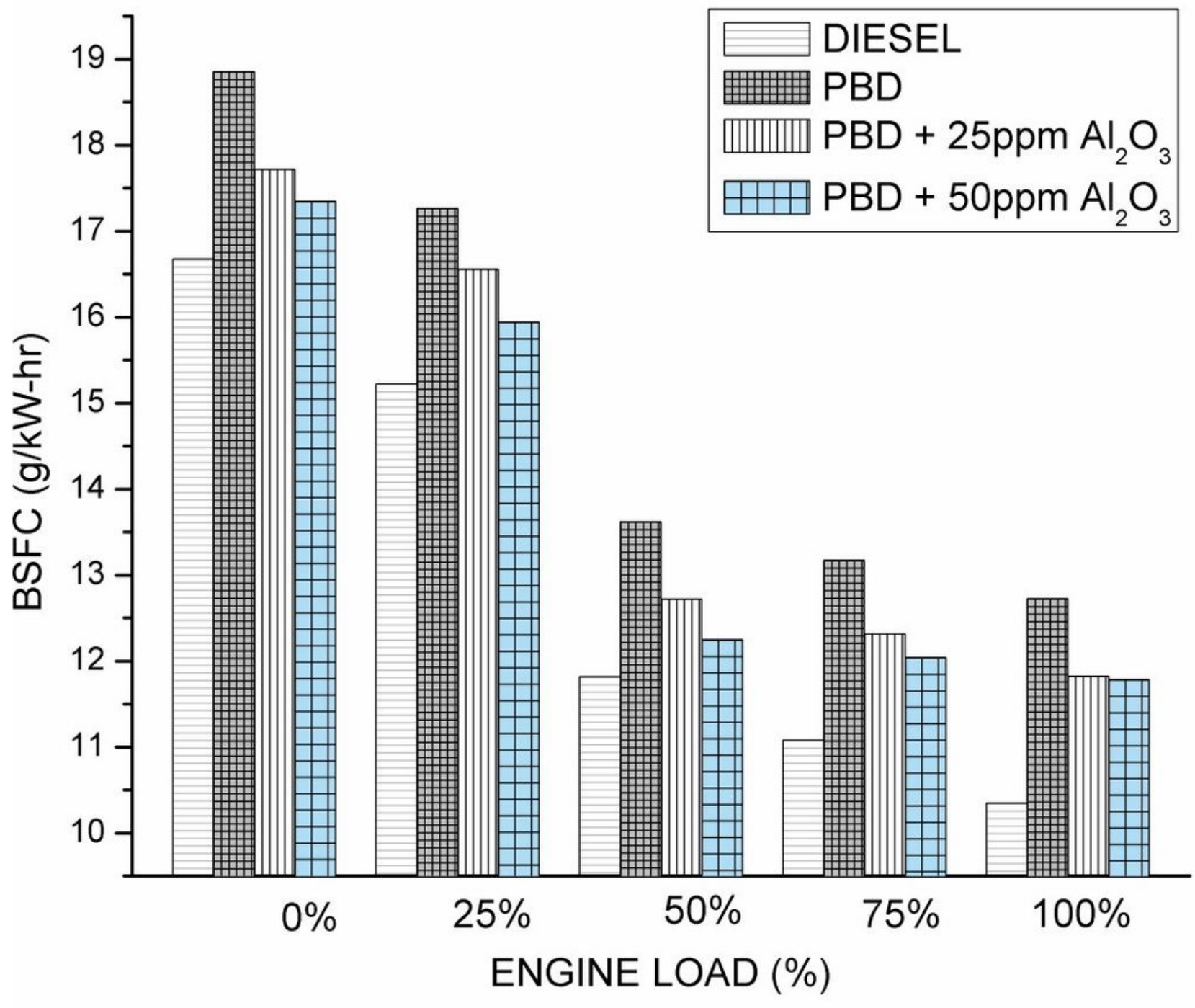

Figure 8

Variation of brake specific fuel consumption (BSFC) with respect to engine load 


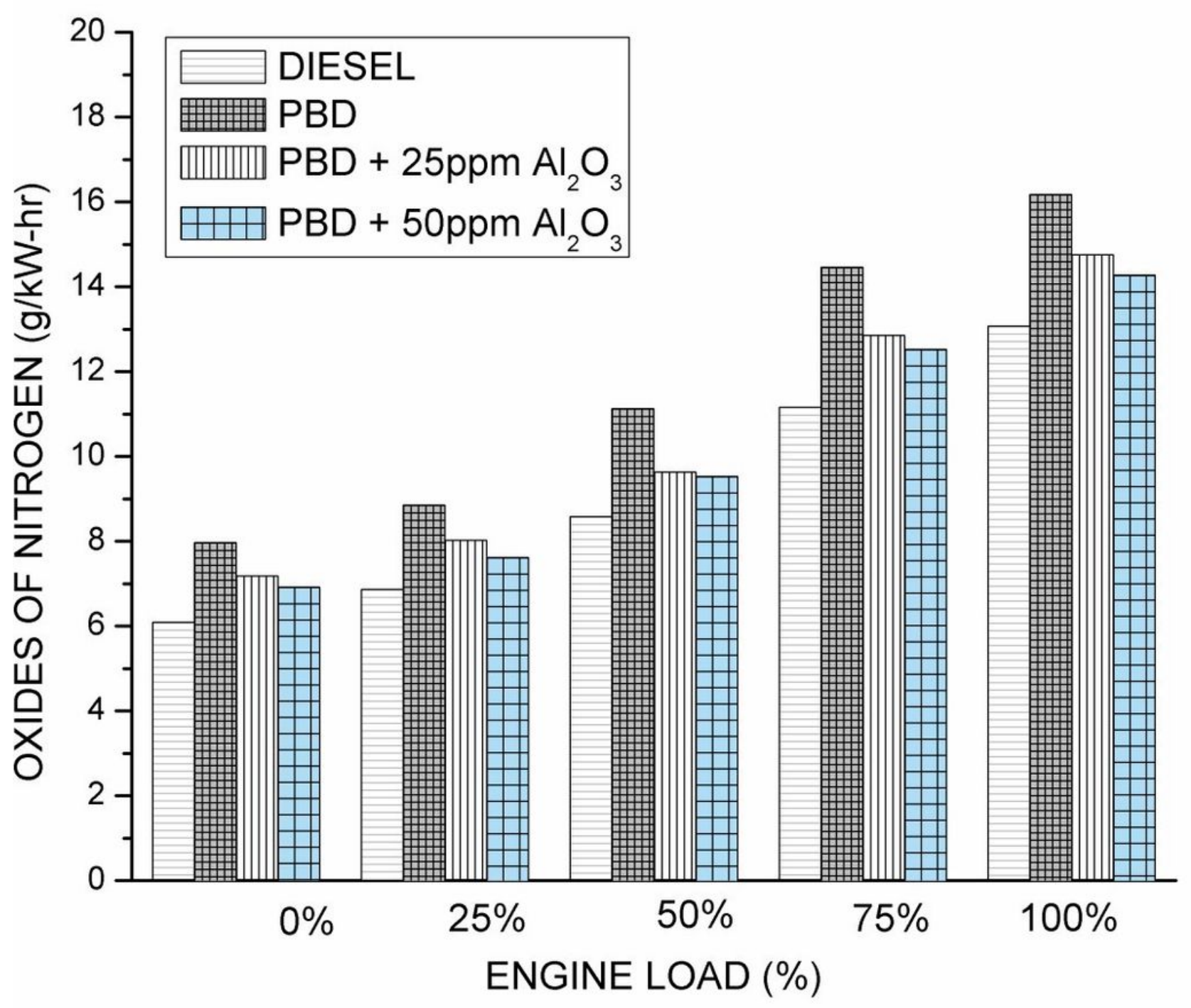

Figure 9

Variation of oxides of nitrogen (NOx) with respect to engine load 


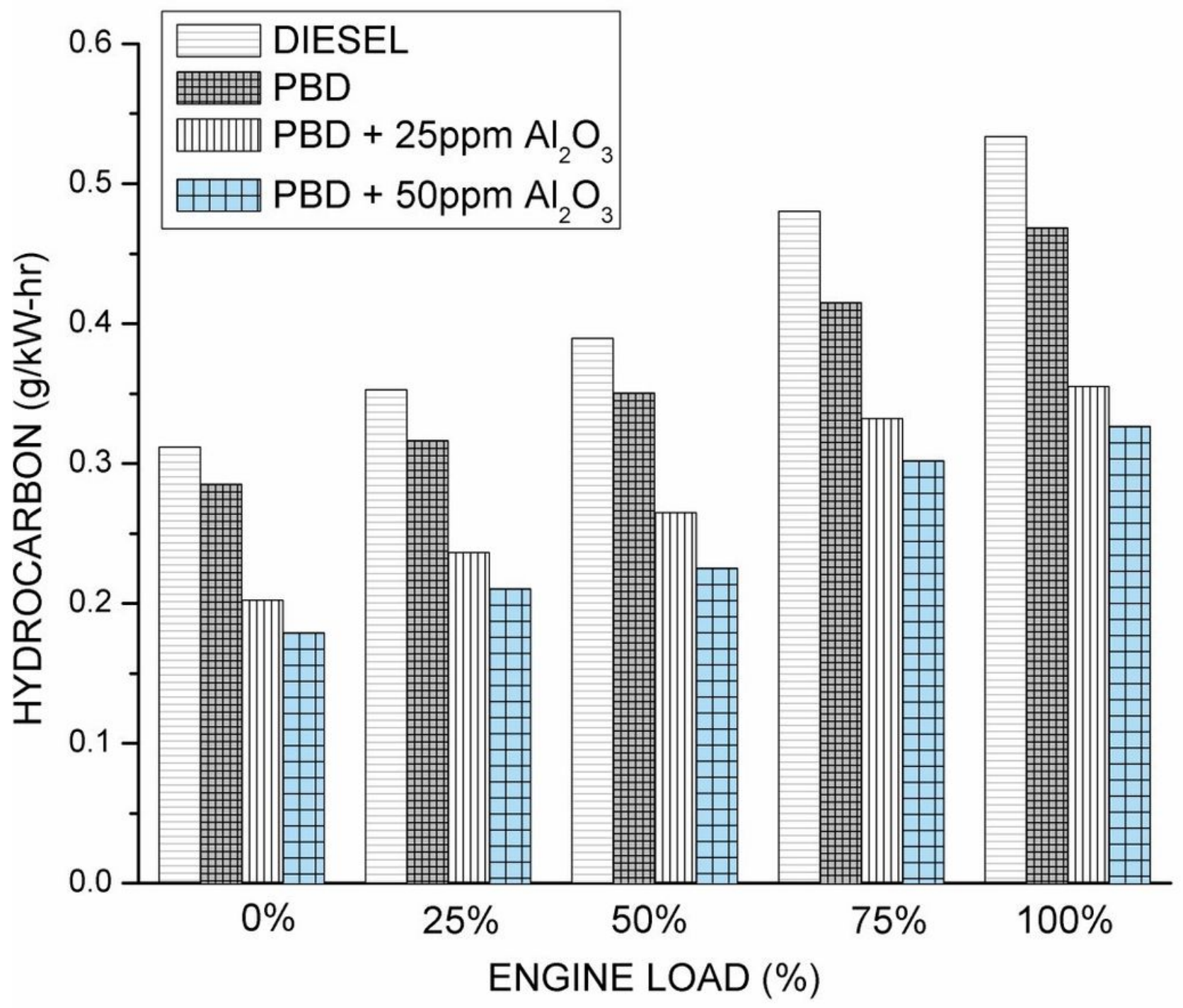

Figure 10

Variation of hydrocarbon $(\mathrm{HC})$ with respect to engine load 


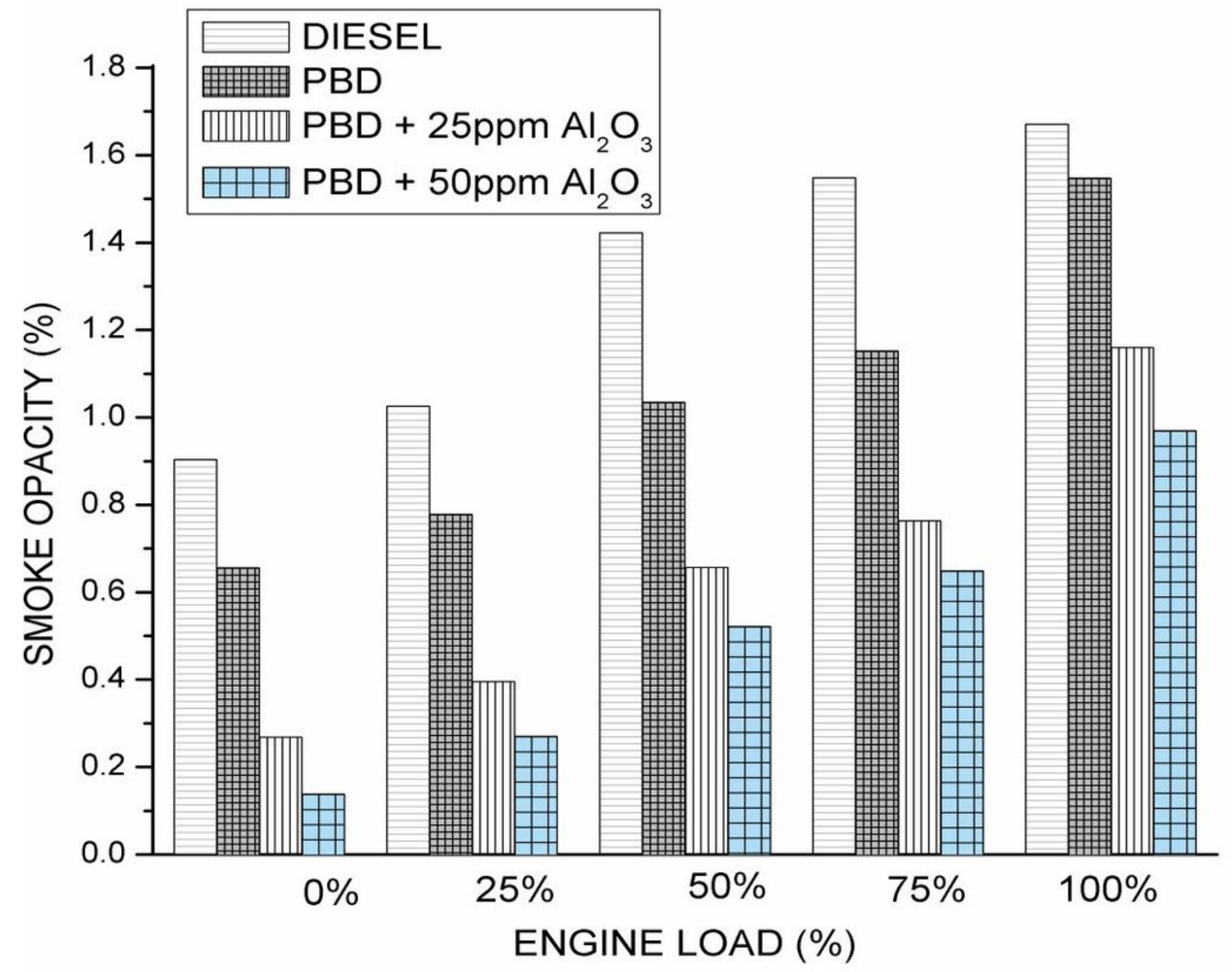

Figure 11

Variation of smoke opacity with respect to brake power 


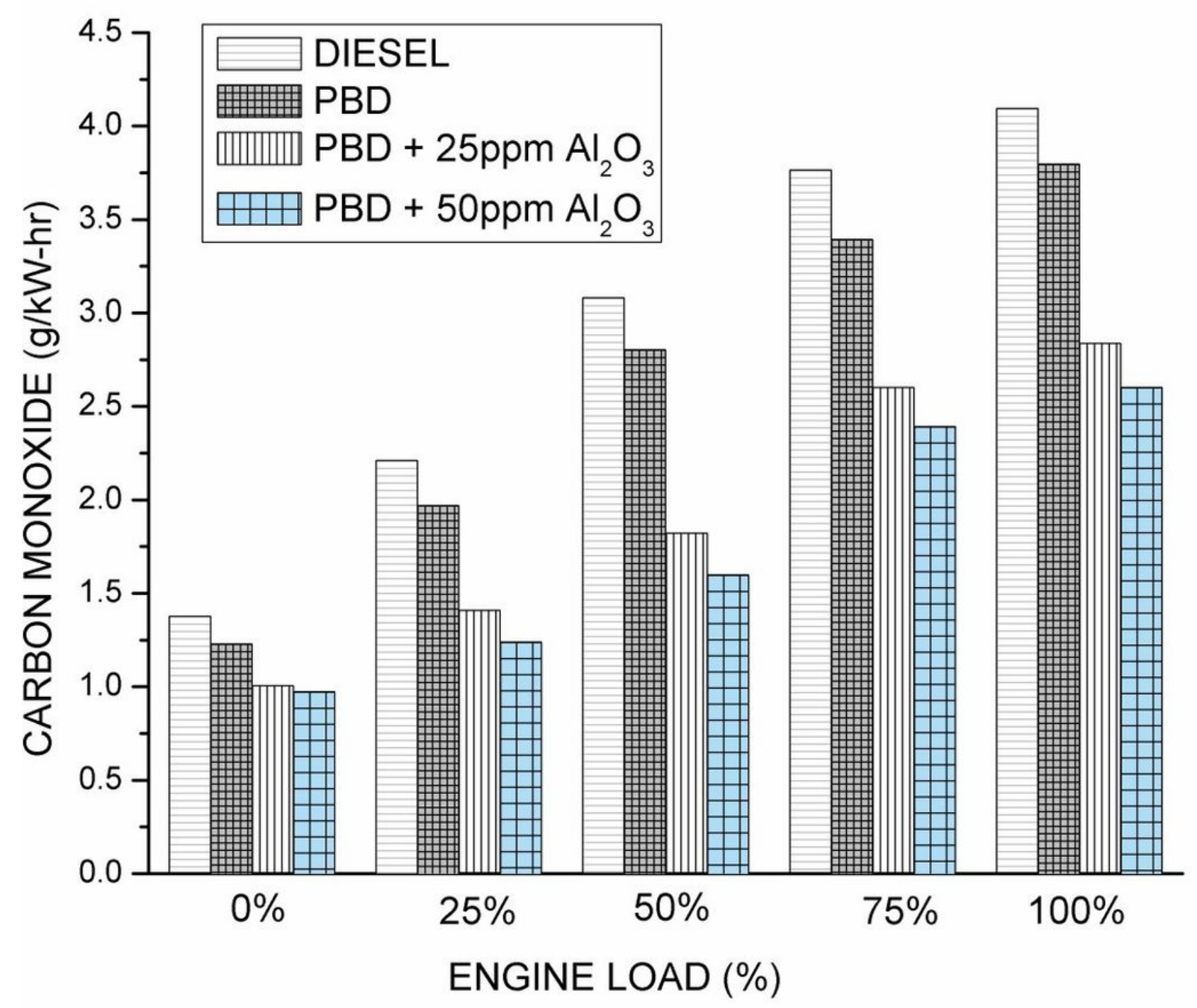

Figure 12

Variation of carbon monoxide (CO) with respect to engine load

\section{Supplementary Files}

This is a list of supplementary files associated with this preprint. Click to download.

- Tables.pdf 